\title{
PROXIMATE COMPOSITION AND ANTIBACTERIAL POTENTIALS OF CULTIVATED GARLIC (ALLIUM SATIVUM L.) AND ONION (ALLIUM CEPA L.) IN ALGERIA
}

\author{
Hasna Bouhenni ${ }^{1}$, Koula Doukani1 ${ }^{*}$, Nazım Şekeroğlu ${ }^{2}$, Souhila Tabak ${ }^{1}$ \\ ${ }^{1 *}$ Laboratory of Agrobiotechnology and Nutrition in Semi-Arid Zones, Faculty of Nature and Life Sciences, \\ University of Ibn Khaldoun, Po.Box 78, Zaaroura ,Tiaret (14000), Algeria; \\ ${ }^{2}$ Department of Food Engineering, Faculty of Engineering and Architecture; Advanced Technology Application and \\ Research Center, Kilis 7 Aralik University, 79000 Kilis, Turkey; \\ *Corresponding author Koula Doukani, e-mail: kouladoukani@gmail.com;
}

Received March 2019; Accepted April 2019; Published June 2019;

DOI: https://doi.org/10.31407/ijees9218 UOI license: http://u-o-i.org/1.01/ijees/58407944

\begin{abstract}
Garlic (Allium sativum L.) and onion (Allium cepa L.) are ones of the most promising medicinal herbs known from ancient times having nutritional value. Nutrients found in these medicinal plants play important roles in curing different diseases and disorders. Therefore, the present study aimed to determine the physico-chemical characteristics of cultivated varieties of garlic and onion and evaluate the antibacterial activity of these plants by disk diffusion method against three pathogenic strains including Staphylococcus aureus ATCC 25923, Escherichia coli ATCC 25922 and Bacillus subtilis ATCC 25332.The physico-chemical analysis executed was $\mathrm{pH}$, titratable acidity, moisture, ash, total soluble solids, electrical conductivity, viscosity, proteins, fats, crude fiber, pectin, total and reducing sugars and minerals. It was found that these plants are good source of proteins, fats, fibers, minerals and energy. The results of antibacterial activity, methanol extract obtained from these plants revealed the sensitivity on the tested pathogenic strains. The strongest antibacterial effect on tested strains was found in garlic extracts.
\end{abstract}

Key words: Garlic, Onion, Physico-chemical, Antibacterial, Pathogenic strains 